\title{
Immobilization by Surface Conjugation of Cyclic Peptides for Effective Mimicry of the HCV-Envelope E2 Protein as a Strategy toward Synthetic Vaccines
}

\author{
Theodorus J. Meuleman, ${ }^{\dagger}$ James I. Dunlop, ${ }^{\ddagger}$ Anna M. Owsianka, ${ }^{\ddagger}$ Helmus van de Langemheen, ${ }^{\dagger}$
} Arvind H. Patel, ${ }^{*}+$ and Rob M. J. Liskamp* ${ }^{*}+0$

${ }^{\dagger}$ School of Chemistry, University of Glasgow, Joseph Black Building, University Avenue, Glasgow G12 8QQ, United Kingdom

${ }^{\ddagger}$ MRC-University of Glasgow Centre for Virus Research, Garscube Campus, Sir Michael Stoker Building, 464 Bearsden Road, Glasgow G61 1QH, United Kingdom

Supporting Information

ABSTRACT: Mimicry of the binding interface of antibody-antigen interactions using peptide-based modulators (i.e., epitope mimics) has promising applications for vaccine design. These epitope mimics can be synthesized in a streamlined and straightforward fashion, thereby allowing for high-throughput analysis. The design of epitope mimics is highly influenced by their spatial configuration and structural conformation. It is widely assumed that for proper mimicry sufficient conformational constraints have to be implemented. This paper describes the synthesis of bromide derivatives functionalized with a flexible TEG linker equipped with a thiol-moiety that could be used to support cyclic or linear peptides. The cyclic and linear epitope mimics were covalently conjugated via the free thiol-moiety on maleimide-activated plate surfaces. The resulting covalent, uniform, and oriented coated surface of cyclic or linear epitope mimics were subjected to an ELISA to investigate the effect of peptide cyclization with respect to mimicry of an antigen-antibody interaction of the HCV E2 glycoprotein. To the best of our knowledge, the benefit of cyclized peptides over linear peptides has been clearly demonstrated here for the first time. Cyclic epitope mimics, and not the linear epitope mimics, demonstrated specificity toward their monoclonal antibodies HC84.1 and V3.2, respectively. The described strategy for the construction of epitope mimics shows potential for high-throughput screening of key binding residues by simply changing the amino acid sequences within synthetic peptides. In this way, leucine-438 has been identified as a key binding residue for binding monoclonal antibody V3.2.

\section{INTRODUCTION}

Hepatitis C Virus ( $\mathrm{HCV})$ poses a global threat and is estimated to have infected over $3 \%$ of the world's population. ${ }^{1}$ So far, its high mutation rate and intrinsic immune evasive strategies have hampered development of therapeutic and prophylactic vaccines. Despite this and the availability of novel antivirals, ${ }^{2}$ there is an urgent need for the development of HCV vaccines, ${ }^{3}$ since drugs do not prevent reinfection ${ }^{4}$ and their treatment is expensive. ${ }^{3}$ The potential of these possible future vaccines is underlined by the existence of antibodies capable of preventing viral infection (i.e., Neutralizing Antibodies (NAbs)). ${ }^{5}$

Evidently, the HCV E2 envelope glycoprotein is of major importance for development of $\mathrm{HCV}$ vaccines, ${ }^{6}$ as it is involved in viral attachment and entry, and is therefore an accessible target located on the surface of the virion. However, generating NAbs against this glycoprotein is not straightforward as it contains highly variable immunogenic domains. Antibodies against these regions tend to be strain-specific and unable to prevent infection by a different strain of $\mathrm{HCV}$. These variable epitopes serve as decoys to distract the immune system. In addition, HCV E2 contains $11 \mathrm{~N}$-linked glycans that can shield certain epitopes, thereby preventing binding of antibodies.
Nevertheless, numerous NAbs have been isolated from patient sera that are able to inhibit infection by a broad range of $\mathrm{HCV}$ isolates. Most of these broadly neutralizing antibodies bind to conserved, discontinuous regions within the HCV E2 glycoprotein and block its interaction with the CD81 receptor. ${ }^{8}$ These regions are designated as broadly neutralizing epitopes. $^{5,9-11}$ The availability of structural information on these HCV E2 neutralizing epitope-antibody interactions might be crucial for future vaccine design. $5,10,12,13$

A decade ago we introduced a chemical biology perspective for designing synthetic vaccines by describing a strategy for mimicry of discontinuous protective epitopes using a synthetic scaffold for obtaining a 'PEPTAC' molecular construct, which acted as a synthetic vaccine and protected mice against infection with B. pertussis. ${ }^{14}$ Although this was a very promising result, we think in order to further improve chances for ultimately a successful synthetic $\mathrm{HCV}$ vaccine, we have to mimic neutralizing epitopes present in E2 as closely as possible

Received: November 30, 2017

Revised: January 24, 2018

Published: January 31, 2018 
and ligate them on a diversity of suitable scaffold molecules. $^{15-17}$

The required scaffold molecule should mimic the structural integrity that is normally provided for by the majority of a protein (Figure 1). Thus, the resulting epitope containing

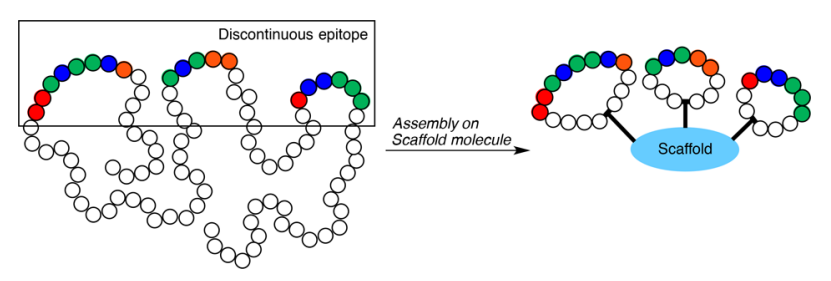

Figure 1. Epitope mimicry, in which essential peptide loops of a discontinuous epitope are ligated on a molecular scaffold.

protein mimic will only present the essential epitope(s) and will not contain any shielding or immunogenic decoy domains. Consequently these protein mimics have the potential to lead to synthetic and more efficient vaccines. ${ }^{18,19}$

Conformational constraints are probably very important in the design of epitope mimics, since they can induce or enforce conformations of epitopes as they are present in the native protein. ${ }^{15}$ Many epitopes comprise looplike structures, and mimicry of looplike peptide sequences is best achieved by cyclization. Furthermore, introduction of conformational constraints by cyclization has been found to improve rigidity, stability, bioavailability, and biological activity of peptide-based therapeutics. ${ }^{14,17}$ Therefore, constrained peptides are preferred in the design of adequate and effective epitope mimics. ${ }^{20-25}$ However, to the best of our knowledge, this favorable effect on epitope mimicry by the introduction of conformational constraints by cyclization has not been rigorously investigated so far.

The cornerstone of studying antigen-antibody interactions and the identification of promising neutralizing epitopes is the enzyme-linked immunosorbent assay (ELISA). With respect to this, novel isolated NAbs, obtained from immunization studies or patients, are tested by ELISA to verify binding. ${ }^{9,26,27}$ Key binding residues of antigen-antibody interactions are identified (i.e., epitope mapping) using mutagenesis studies, in which ELISA is used to assess the altered binding affinity of antibodies toward different mutants., ${ }^{9,28}$ Conventional ELISA involves noncovalent adsorption of antigen(s) on polystyrene plates, which likely results in a heterogeneous surface of differently adsorbed antigen molecules. Thus, these will probably interact with different affinities with antibodies. ${ }^{29}$ In addition, adsorption of antigens on polystyrene plates could potentially perturb the structure of the antigen, thereby also influencing antibody binding. Gori et al. have shown the importance of accurate control of covalent immobilization and generating a uniform and oriented surface for proper gauging of antigenantibody interactions using peptide sequences. ${ }^{30}$

In this research we show the importance of cyclization of peptides as a conformational constraint for effective mimicry of neutralizing epitopes from HCV E2. To this end, more flexible, linear peptides were compared with their constrained, cyclic counterparts. These peptide constructs were obtained via benzylic bromide derivatives equipped with a tetraethylene glycol (TEG) spacer containing a trityl-protected thiol-moiety ( 7 and 8 , respectively). After liberation of the thiol moiety, instead of random noncovalent adsorption, a covalent coating of epitope mimics on polystyrene plates was obtained using commercially available Pierce maleimide activated 96-well plates (Figure 2).

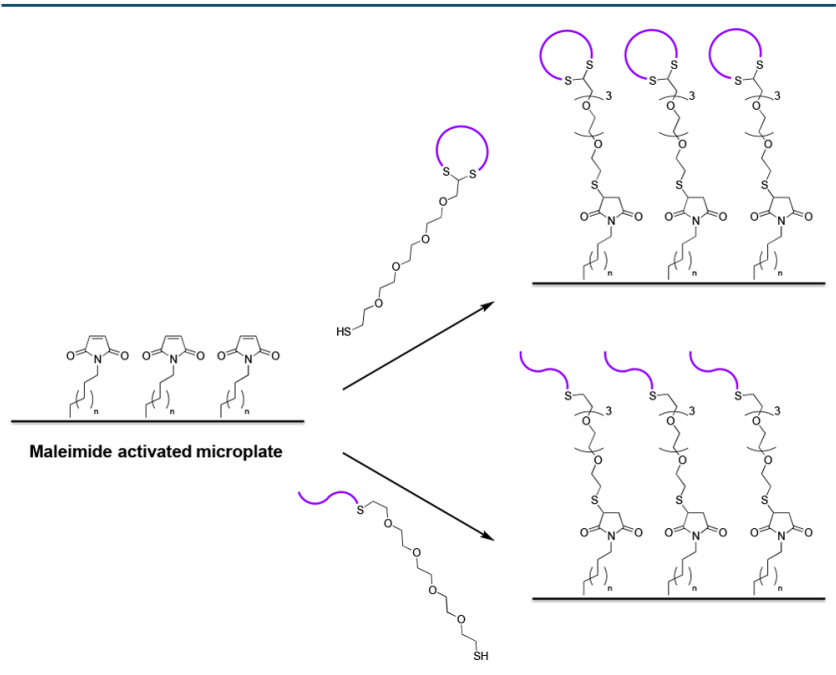

Figure 2. Chemoselective approach for covalent immobilization of epitope mimics in a uniform and specifically oriented fashion via thiol addition to maleimide.

The availability of a human/mouse antibody variant of the broadly neutralizing human monoclonal antibody (mAb) HC84.1, ${ }^{9}$ as well as weakly neutralizing mouse antibody V3.2 (to be published), enabled us to evaluate our epitope mimics using ELISA and the impact of peptide cyclization for effective mimicry.

\section{RESULTS AND DISCUSSION}

Synthesis of the Peptide Cyclization and Linear Linker with a Maleimide Reactive Tetraethylene Glycol (TEG) Spacer. Recently, we introduced a bisbromobenzyl azide derivative for cyclization of dicysteine containing peptides and subsequent $\mathrm{Cu}$-catalyzed azide-alkyne cyclo-addition to alkyne containing scaffold molecules. ${ }^{14,17}$ Here a related bisbromobenzyl derivative was required, having instead of an azide functionality a TEG moiety for improved water solubility and a (protected) thiol group for reaction with maleimide moieties present on the surface of an ELISA plate. $^{31}$

Thus, TEG 1 was monotosylated to tosylate 2 (61\%) followed by substitution using crude trityl-thiol 3 leading to trityl-TEG-sulfide 4 (quant.). Next, the cyclization linker moiety was introduced in a reaction with 1,3,5-tris(bromomethyl)benzene $\mathbf{5}$ and trityl protected cyclization linker 7 was obtained in a moderate yield (33\%) (Scheme 1). Similarly, trityl-TEGsulfide 4 was reacted with 1,3-bis(bromomethyl)benzene 6 , to provide trityl protected linear linker 8 also in a moderate yield (43\%). Di- and trisubstituted products were observed during the reaction of cyclic linker 7 and linear linker 8 , which at least partially explained the lower yields of the mono substituted products. The availability of both scaffolds supporting cyclized or linear peptide constructs was essential for a rigorous evaluation of the constraining effects by peptide cyclization.

Alkylation of Cysteine Containing Peptides with Linkers 7 or 8 . The required mono- or dicysteine containing peptides were obtained by solid phase peptide synthesis. Their amino acid sequences originated from Epitope II present in HCV E2 glycoprotein $\left(\mathrm{N}^{434}\right.$ TGWLAGLFYQHK ${ }^{446}$; residues 
Scheme 1. Synthesis of PEG-Based Thiol Linkers for Peptides Cyclization/Attachment and Conjugation to Plates

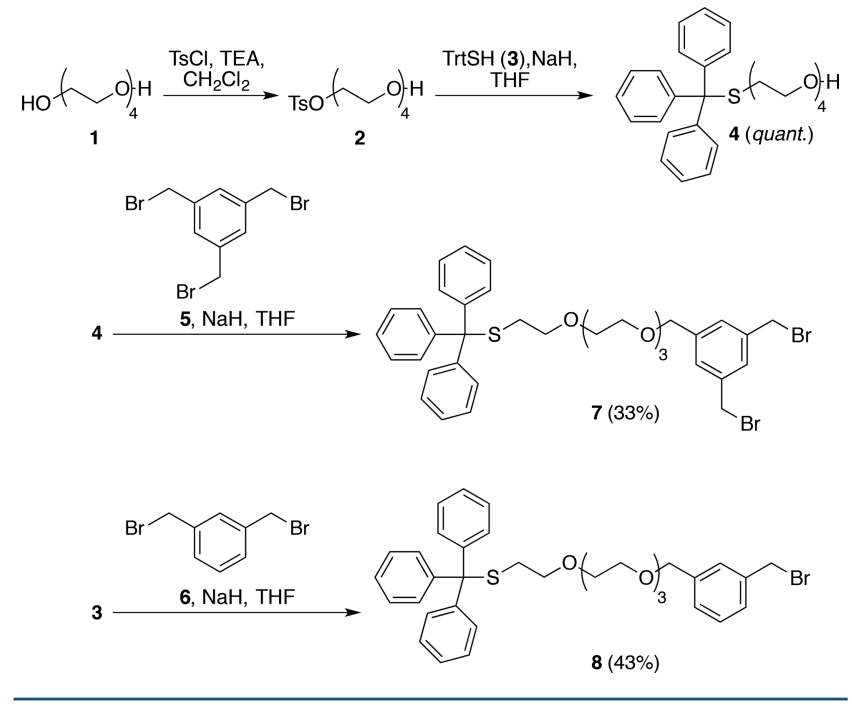

in bold are highly conserved across genotypes). ${ }^{9,10,32,33}$ Epitope II is a neutralizing immunogenic domain recognized by NAb HC84.1 and weakly by NAb V3.2 (to be published). Epitopes of mAb HC84.1 and V3.2 have been mapped to HCV E2 residues 439 to $446^{9,10}$ and residues 435 to 442 (to be published), respectively. The available sequence information of the different HCV genotypes/strains allowed for the optimization of epitope II toward consensus sequences corresponding to residues 436 to 448 and 430 to 444 of peptides shown in Table 1, which cover multiple genotypes of HCV.

Peptides 9 (cp), 11 (cp), 13 (cp), and 14 (cp) served as cyclization precursor (cp) peptides for the preparation of the cyclic peptide constructs $15,17,19$, and 20 , respectively, and were synthesized with a cysteine residue at both $\mathrm{N}$ - and $\mathrm{C}$ termini. Linear precursor (lp) peptides 10 (lp) and 12 (lp) containing one cysteine residue were synthesized to prepare the linear peptide constructs 16 and 18. In addition, peptide 14 (cp) was designed with a scrambled amino acid sequence and synthesized for the preparation of cyclic peptide construct $\mathbf{2 0}$ to serve as a negative control, which should not bind to the available MAbs HC84.1 and V3.2.

Synthesis of the Epitope Mimics for Surface Conjugation. Reaction of the thus-synthesized precursor peptides with either linker construct 7 or 8 led to cyclic peptide constructs 15, 17, 19, and 20 and linear peptide constructs 16 and $\mathbf{1 8}$, respectively (Scheme 2 ).

Scheme 2. Alkylation of Precursor Peptides with the Linker Constructs 7 or 8

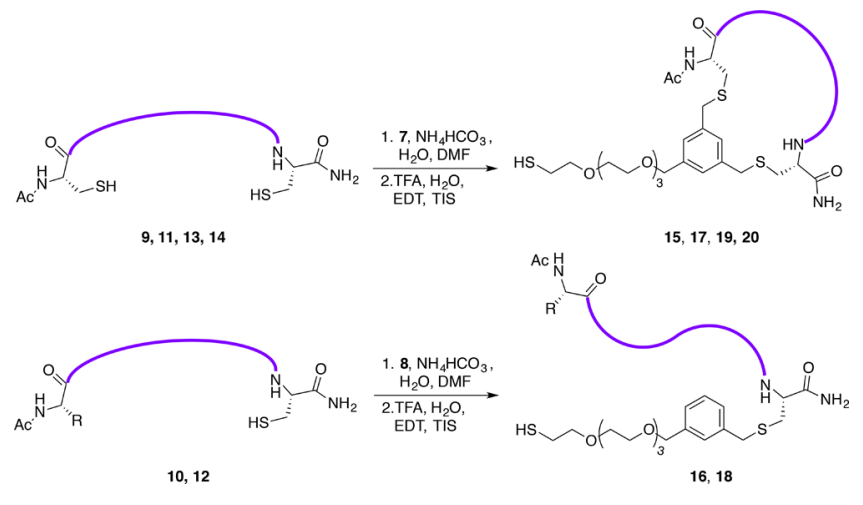

This alkylation procedure is convenient since it can be carried out using the crude, fully deprotected peptides. If the peptides exhibit good water solubility then normally $\mathrm{NH}_{4} \mathrm{HCO}_{3}$ in a mixture water/acetonitrile can be used. However, since our peptides were much more hydrophobic, dimethylformamide (DMF) had to be included for dissolving the peptides and the alkylation approach was optimized to dissolve the peptide and the linker in a concentration of $1 \mathrm{mM}$ in aqueous $\mathrm{NH}_{4} \mathrm{HCO}_{3}$ buffer (20 mM; pH 7.9) in DMF (75\%). Immediately after alkylation of the peptide on the linker, the trityl group was removed to liberate the thiol functionality.

Purification of the epitope mimics was achieved by preparative reverse phase HPLC. The TEG spacer improved the aqueous solubility of the cyclic epitope mimics $(15,17,19$, and 20), slightly. The linear epitope mimics (16 and 18) showed a significantly better solubility upon attachment of the TEG containing linker. Nevertheless, all epitope mimics were

Table 1. Overview of the Synthesized Peptidic Antigen Sequences Based on Epitope II of HCV E2 Glycoprotein ${ }^{a}$

\begin{tabular}{|c|c|c|c|c|c|c|c|c|c|c|c|c|c|c|c|c|c|c|}
\hline $9(\mathrm{cp})$ & & & & & \multicolumn{3}{|c|}{$A c-C G^{436} W$} & V & $A$ & G & $\mathrm{L}$ & $\mathrm{F}$ & $\mathrm{Y}$ & $Y$ & $\mathrm{H}$ & $\mathrm{K}$ & $\mathrm{F}$ & $\mathrm{N}^{448} \mathrm{C}-\mathrm{NH}_{2}$ \\
\hline $10(\mathrm{lp})$ & & & & & \multicolumn{3}{|c|}{$A c-G^{436} W$} & V & $A$ & G & $\mathrm{L}$ & $\mathrm{F}$ & $\mathrm{Y}$ & $Y$ & $\mathrm{H}$ & $\mathrm{K}$ & $\mathrm{F}$ & $\mathrm{N}^{448} \mathrm{C}-\mathrm{NH}_{2}$ \\
\hline $11(\mathrm{cp})$ & $A c-C \quad N^{430} E$ & $S$ & $\mathrm{~L}$ & $\mathrm{~N}$ & $\mathrm{~T}$ & $G$ & W & $\mathrm{L}$ & $A$ & $\mathrm{G}$ & $\mathrm{L}$ & $\mathrm{F}$ & $Y$ & $Y^{444}$ & \multicolumn{3}{|c|}{$\mathrm{C}-\mathrm{NH}_{2}$} & \\
\hline $12(\mathrm{lp})$ & $A c-N^{430} E$ & $\mathrm{~S}$ & L & $\mathrm{N}$ & $\mathrm{T}$ & G & W & $\mathrm{L}$ & $A$ & $\mathrm{G}$ & $L$ & $\mathrm{~F}$ & $\mathrm{Y}$ & $Y^{444}$ & \multicolumn{3}{|c|}{$\mathrm{C}-\mathrm{NH}_{2}$} & \\
\hline $13(\mathrm{cp})$ & & & & & \multicolumn{3}{|c|}{$A c-C G^{436} W$} & $\mathrm{~L}$ & A & G & $\mathrm{L}$ & $\mathrm{F}$ & $Y$ & $Y$ & $\mathrm{H}$ & $\mathrm{K}$ & $\mathrm{F}$ & $\mathrm{N}^{448} \mathrm{C}-\mathrm{NH}_{2}$ \\
\hline $14(\mathrm{cp})$ & & & & & $A c-$ & $\mathrm{H}$ & $\mathrm{F}$ & $G$ & $\mathrm{~K}$ & $Y$ & $A$ & $\mathrm{~F}$ & W & $\mathrm{L}$ & G & $\mathrm{N}$ & $Y$ & $\mathrm{C}-\mathrm{NH}$ \\
\hline
\end{tabular}

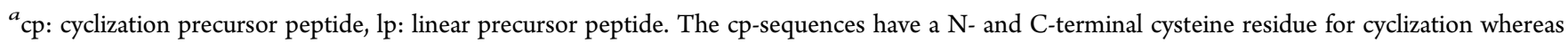
the lp sequences have just one C-terminal residue for attachment to the spacer. Peptide $\mathbf{1 4}$ has the scrambled sequence for preparation of the negative control 20. 

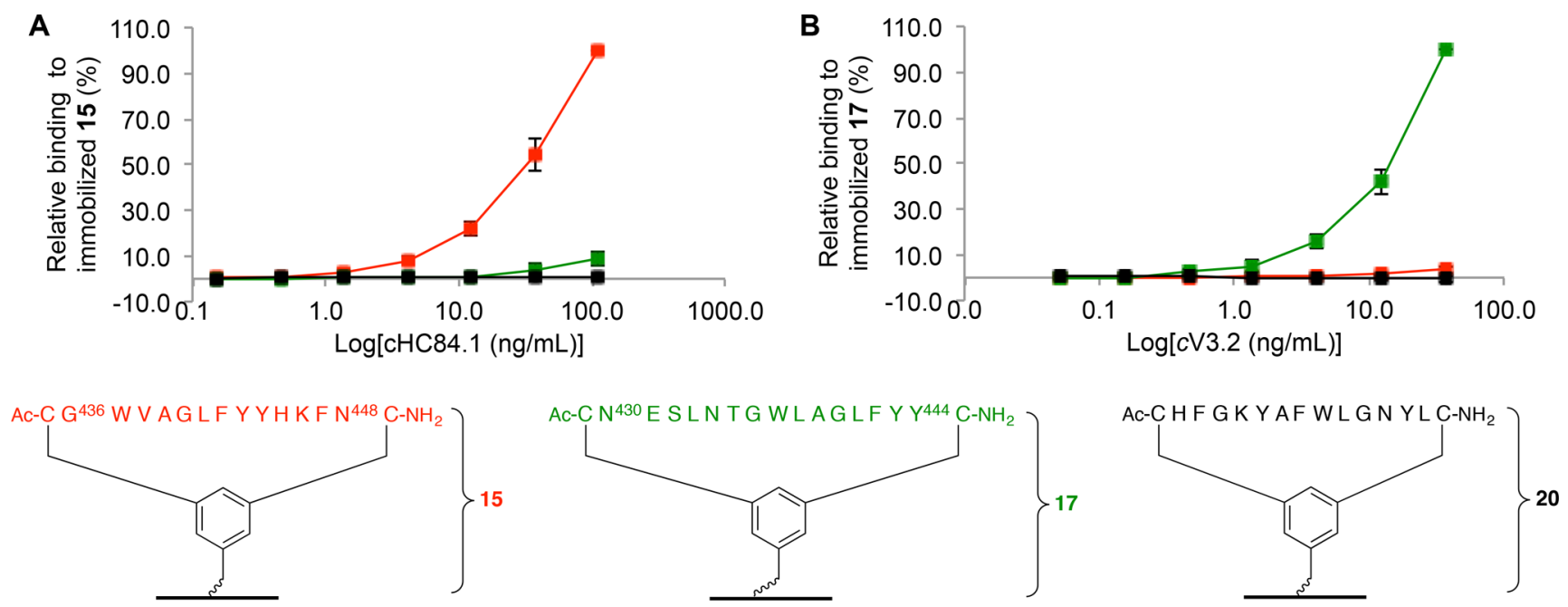

Figure 3. ELISA comparing the immobilized cyclic epitope mimics 15 and 17 with the immobilized cyclic scrambled epitope 20 using MAbs HC84.1 and V3.2. (A) mAb HC84.1 (3-fold dilution over 7 steps [111.1-0.2 ng/mL]); (B) mAb V3.2 (3-fold dilution over $7 \mathrm{steps}[37.0-0.1 \mathrm{ng} / \mathrm{mL}]$ ). Background signal (no $\mathrm{mAb}$ ) was subtracted. The data is represented as a percentage relative to the highest absorbance being set to $100 \%$ per individual experiment (A: 15; B: 17). Data was collected from 3 to 5 independent experiments, each performed in duplicate. Error bars represent the standard deviation.
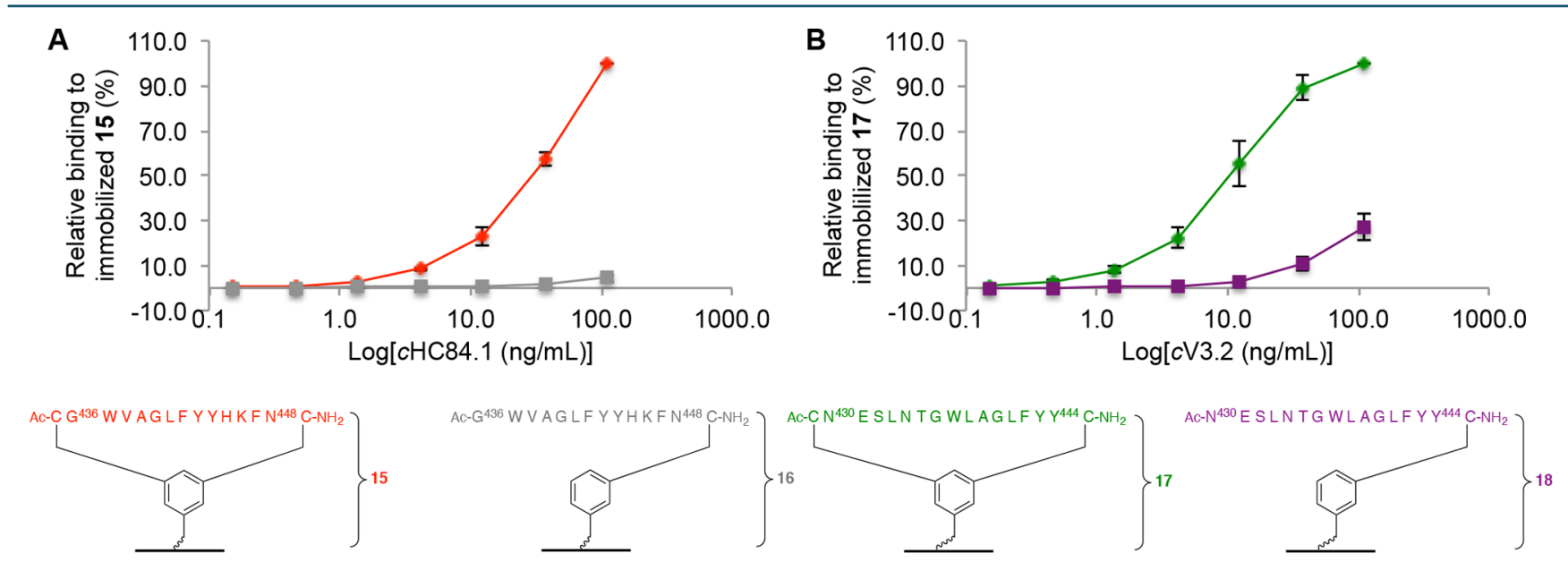

Figure 4. ELISA evaluating the effect of cyclization by comparing the immobilized cyclic peptides $\mathbf{1 5}$ and $\mathbf{1 7}$ with the corresponding linear epitope mimics 16 and 18 using MAbs HC84.1 and V3.2. (A) mAb HC84.1 (3-fold dilution over by 7 steps [111.1-0.2 ng/mL]); (B) mAb V3.2 (3-fold dilution over 7 steps $[111.1-0.2 \mathrm{ng} / \mathrm{mL}]$ ). Background signal (no mAb) was subtracted. The data is represented as a percentage relative to the highest absorbance being set to $100 \%$ per individual experiment (A: 15; B: 17). Data was collected from 3 independent experiments, each performed in duplicate. Error bars represent the standard deviation.

obtained in reasonable purity and yields, ranging between $90 \%$ and $95 \%$ purity overall with $4-17 \%$ yield for the cyclic peptide constructs $15,17,19$, and 20 and $4-30 \%$ yield for the linear peptide constructs $\mathbf{1 6}$ and $\mathbf{1 8}$. In our group, Van de Langemheen et al. recently developed polar hinges that may be used for future improvement of the general solubility of more hydrophobic peptides in cyclization reactions. ${ }^{34}$

Immobilization by Surface Conjugation to Immobilized Maleimide Residues. To improve conventional ELISA, the individual epitope mimics were covalently ligated onto maleimide-activated plates. To verify antibody recognition of the cyclic epitope mimics $(15,17$, and 20$)$ coated plate surface, plates were incubated with a 3-fold dilution series of MAbs HC84.1 and V3.2. It was observed that binding of mAb HC84.1 was specific toward 15 (Figure $3 \mathrm{~A}$ ) and binding of $\mathrm{mAb}$ V3.2 was specific toward 17 (Figure $3 \mathrm{~B}$ ). As expected, the negative control containing a scrambled peptide sequence (20) did not bind either mAb HC84.1 or V3.2. As mentioned before, cyclic epitope mimics 15 and 17 are both based on the epitope II region. However, the two MAbs HC84.1 and V3.2 bind epitope II via different residues. Therefore, by using the different synthetic peptides 9 (cp) or $\mathbf{1 1}(\mathrm{cp})$ it is possible to demonstrate selectivity of the MAbs toward their respective cyclic epitope mimics 15 and 17 (Figure 3).

Impact of Peptide Cyclization For Adequate Mimicry of E2 Peptide Loops. To understand the impact of cyclization in mimicry of epitopes, we studied the binding of MAbs HC84.1 and V3.2 to cyclic and linear epitope mimics. To this end, the cyclic (15 and 17) and linear (16 and 18) epitopes mimics were ligated separately on maleimide-activated plates. The covalently ligated surfaces were incubated with a 3 -fold dilution series of MAbs HC84.1 and V3.2. A significant difference in antibody binding was observed between the immobilized cyclic and linear epitope mimics, for both MAbs HC84.1 and V3.2 (Figure 4). mAb HC84.1 successfully bound cyclic epitope mimic 15, but did not show any binding to the 

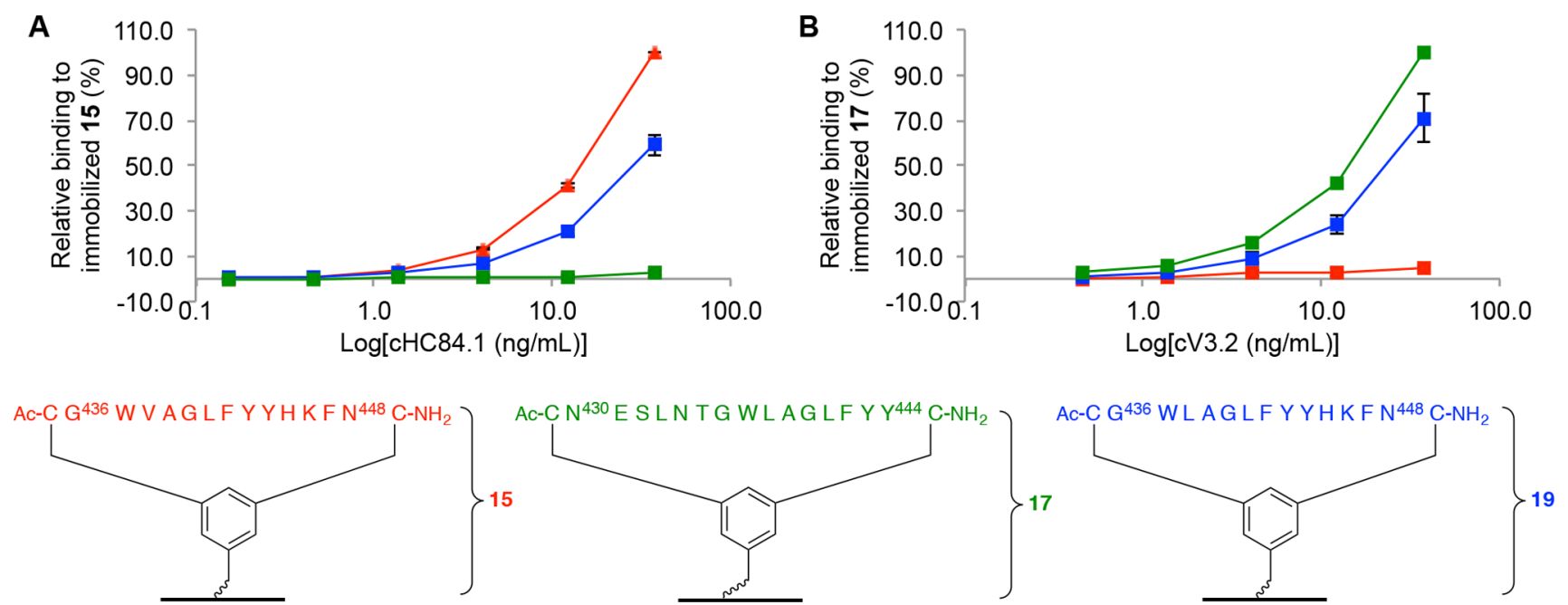

Figure 5. ELISA showing the relative importance of different immobilized cyclic epitope mimics 15, 17, and 19 toward binding of MAbs HC84.1 and V3.2. (A) mAb HC84.1 (3-fold dilution over 6 steps [37.0-0.2 ng/mL]); (B) mAb V3.2 (3-fold dilution over 5 steps [37.0-0.5 ng/mL]). Background signal (no $\mathrm{mAb}$ ) was subtracted. The data is represented as a percentage relative to the highest absorbance being set to $100 \%$ per individual experiment (A: 15; B: 17). Data was collected from 3 independent experiments, each performed in duplicate. Error bars represent the standard deviation.

corresponding linear epitope mimic 16 (Figure 4A). In addition, mAb V3.2 was capable of binding cyclic epitope mimic 17 but showed almost no binding to the corresponding linear epitope mimic $\mathbf{1 8}$ (Figure 4B). These results strongly emphasize the importance of peptide cyclization for antibody recognition, which in turn advocates peptide cyclization for accurate mimicry of epitopes. The difference between $\mathrm{mAb}$ HC84.1 not binding linear epitope mimic $\mathbf{1 6}$ at all and $\mathrm{mAb}$ V3.2 binding linear epitope mimic 18 to a minor extent suggests that the importance of peptide cyclization could be sequence dependent. Perhaps, certain linear peptides readily resemble the conformation of cyclized peptides.

Cyclization of our peptide sequence resulted in epitope mimics that exhibit a higher affinity toward antibodies. This serves as direct evidence that conformational constraints in peptides resulted in improved mimicry. Nevertheless, the flexibility of linear peptides might allow certain conformations to mold themselves onto binding interfaces, similar to a lock and key model. Krey et al. have successfully cocrystallized human mAb HC84.1 bound to a linear peptide based on the Epitope II region of HCV E2. ${ }^{10}$ The human mAb HC84.1 has been shown to bind the peptide in a $\alpha$-helical conformation. Perhaps, the linear peptide has adopted partially an $\alpha$-helix in solution or an $\alpha$-helix was induced upon binding to HC84.1. In this work, the linear epitope mimic 16 showed a major detrimental effect on binding mAb HC84.1, which could indicate the inability of linear precursor peptide $\mathbf{1 0}(\mathrm{lp})$ to form a necessary $\alpha$-helical structure while alkylated on the linker. However, binding of mAb HC84.1 was achieved by immobilized cyclic epitope mimic 15, which suggests that the required interacting conformation of the flexible linear peptide might be enforced by cyclization. Since epitope mimicry is based on individual peptide sequences of proteins being grafted on molecular scaffolds, it is inevitable that the intrinsically adopted conformations of linear peptides will be influenced. Therefore, conformational constraints are necessary to preorganize the peptides into the required conformations. Nevertheless, it is not assumed that our cyclized peptides behave similarly to stapled peptides in which the $\alpha$-helix character is enhanced by side chain cyclization, since stapling usually involves cyclization by Ring Closing Metathesis (RCM) of (disubstituted) amino acid residues $i$ and $i+4$ or residues $i$ and $i+7$. In peptide $\mathbf{1 5}$ side chains of residues $i$ and $i+14$ are connected.

Employing Epitope Mimic Coated Surfaces for Identification of Key Binding Residues. Since cyclic peptide precursor $\mathbf{1 1}(\mathrm{cp})$ is elongated at the $\mathrm{N}$-terminus compared to peptide cyclic peptide precursor 9 (cp), some degree of cross-reactivity of MAbs HC84.1 and V3.2 was expected toward both cyclic epitope mimics 15 and 17 . However, no such cross-reactivity was observed at the antibody concentrations used. Interestingly, residues involved in binding mAb HC84.1 $\left({ }^{437} \mathrm{~W},{ }^{441} \mathrm{~L},{ }^{442} \mathrm{~F},{ }^{443} \mathrm{Y}\right){ }^{9}$ or mAb V3.2 might differ. Typically, mutagenesis studies are used to identify key binding residues within epitopes involved in antibody recognition. For these, several recombinant mutants of E2 have to be generated that are screened in ELISA to evaluate the altered binding affinity of the antibodies. The process of generating a multitude of different recombinant $\mathrm{E} 2$ sequences is a rather laborious and time-consuming process. Instead, epitope mimics could be used as a more high-throughput screening method as collections of synthetic peptides can be easily obtained in a fast and automated fashion. Subsequently, the different synthetic peptides can be conveniently cyclized on linker 7, conjugated on maleimide-activated plates, and analyzed using ELISA.

In order to evaluate whether cyclic epitope mimics could be used similar to high-throughput mutagenesis studies for identification of key binding residues, it was decided to try to identify those involved in binding mAb V3.2. The major difference in the overlapping peptide sequence between cyclic precursor peptides $\mathbf{9}(\mathrm{cp})$ and $\mathbf{1 1}$ (cp) is a Valine-to-Leucine change at position 438. To this end, a mutant cyclic precursor peptide 13 (cp) was synthesized that contained a Valine-toLeucine change on position 438 (V438L). Cyclic precursor peptide 13 (cp) was subsequently cyclized to prepare cyclic epitope mimic 19, which was then conjugated on maleimideactivated plates, and tested using ELISA. Monoclonal antibod- 
ies HC84.1 and V3.2 were tested against plate surfaces containing immobilized cyclic epitope mimics $(15,17$, or 19). The cyclic epitope mimic 15 showed good binding of $\mathrm{mAb}$ HC84.1 (Figure 5A) but no binding of $\mathrm{mAb}$ V3.2. In contrast, cyclic epitope mimic 17 showed good binding of mAb V3.2 (Figure 5B). Valine-to-Leucine change containing cyclic epitope mimic 19 showed a small decrease in binding by mAb HC84.1 (Figure 5A), but showed improved binding by mAb V3.2 (Figure 5B). This result suggested that the leucine sequence at position 438 is crucial for binding mAb V3.2.

\section{CONCLUSION}

In conclusion, we have synthesized epitope mimics containing peptides based on Epitope II of the HCV E2 glycoprotein using benzyl bis and mono bromide derivatives functionalized with a flexible TEG spacer equipped with a thiol-moiety. The thiolmoiety enabled chemoselective covalent coating of epitope mimics to a maleimide-activated surface. As a result uniform peptide layers were obtained on a solid surface, for which we hypothesized that the epitope structure is better preserved than when peptides are noncovalently absorbed onto the ELISA plates. In addition, covalent adsorption prevents a gradual leakage of peptides from the surface. The epitope mimics peptide sequences originated from $\mathrm{HCV}$ E2 and were presented as both cyclic and linear peptides, allowing investigation of the necessity of conformationally constraining of peptide sequences for optimal epitope mimicry.

The broadly neutralizing antibody HC84.1 and weakly neutralizing antibody V3.2 that target epitope II of HCV E2, successfully recognized the immobilized cyclic epitope mimics. In addition, it has been shown that cyclization was essential or at least significantly improved recognition of epitope mimics. Although it is widely assumed that introducing conformational constraints for example by cyclization in (synthetic) peptides for effective mimicry of epitopes is crucial or at least beneficial for recognition by antibodies, to the best of our knowledge, this is the first time that this has been demonstrated in a convincing molecular experimental approach.

Thus, we do not pretend that our cyclization method will favor or stabilize a particular secondary structure, but rather will provide a more stable mimic of the spatial structure of the peptide segment in the-in this case-viral envelope protein than is the case when using a linear peptide.

The novel ELISA platform that has been developed here provides an easy, straightforward, and reliable strategy for cyclization of peptides and subsequent conjugation of these cyclic peptides covalently to an ELISA plate. This opens up possibilities for studying antibody-epitope interaction in a high-throughput fashion and might be an attractive tool in vaccine design.

Finally, the use of synthetically modified epitope peptides in which amino acids are replaced instead of using the entire recombinantly mutated proteins for studying the relative binding affinity by antibodies employing this approach is also a particularly promising perspective.

\section{EXPERIMENTAL SECTION}

General Procedures. All reagents and solvents were used as received. Fmoc-amino acids were obtained from Activotec (Cambridge, United Kingdom) and $N, N, N^{\prime}, N^{\prime}$-Tetramethyl-O(6-chloro-1H-benzotriazol-1-yl)uranium hexafluorophosphate (HCTU) was obtained from Matrix Innovation (Quebec,
Canada). Tentagel S RAM resin (particle size $90 \mu \mathrm{m}$, capacity $0.25 \mathrm{mmol} . \mathrm{g}^{-1}$ ) was obtained from IRIS Biotech (Marktredwitz, Germany). Methyl tert-butyl ether (MTBE), hexane (HPLC grade), and TFA were obtained from Aldrich (Milwaukee, USA). DMF (Peptide grade) was obtained from VWR (Lutterworth, United Kingdom). Piperidine and DiPEA were obtained from AGTC Bioproducts (Hessle, United Kingdom) and 1,2-ethanedithiol (EDT) was obtained from Merck (Darmstadt, Germany). HPLC grade $\mathrm{CH}_{2} \mathrm{Cl}_{2}$ and acetonitrile were obtained from Fischer Scientific (Loughborough, United Kingdom). Solid phase peptide synthesis was performed on a PTI Tribute-UV peptide synthesizer. Lyophilizations were performed on a Christ Alpha 2-4 LDplus apparatus. Reactions were carried out at ambient temperature unless stated otherwise. Solvents were evaporated under reduced pressure at $40{ }^{\circ} \mathrm{C}$. Reactions in solution were monitored by TLC analysis and $\mathrm{R}_{f}$ values were determined on Merck precoated silica gel 60 F-254 $(0.25 \mathrm{~mm})$ plates. Spots were visualized by UV-light and permanganate stain. Column chromatography was performed on Siliaflash P60 $(40-63 \mu \mathrm{m})$ from Silicycle (Canada) or on a Biotage Isolera One purification system using prepacked silica (KP-SIL) Biotage SNAP cartridges. ${ }^{1} \mathrm{H}$ NMR data was acquired on a Bruker 400 $\mathrm{MHz}$ spectrometer in $\mathrm{CDCl}_{3}$ as solvent. Chemical shifts $(\delta)$ are reported in parts per million (ppm) relative to trimethylsilane (TMS, $0.00 \mathrm{ppm}$ ). Analytical high-pressure liquid chromatography (HPLC) was carried out on a Shimadzu instrument comprising a communication module (CBM-20A), autosampler (SIL-20HT), pump modules (LC-20AT), UV/vis detector (SPD-20A), and system controller (Labsolutions V5.54 SP), with a Phenomenex Gemini C18 column $(110 \AA$, $5 \mu \mathrm{m}, 250 \times$ $4.60 \mathrm{~mm}$ ) or Dr. Maisch Reprosil Gold 200 C18 (5 $\mu \mathrm{m}, 250 \times$ $4.60 \mathrm{~mm}$ ). UV measurements were recorded at 214 and 254 $\mathrm{nm}$, using a standard protocol: 100\% buffer A (acetonitrile/ $\mathrm{H}_{2} \mathrm{O} 5: 95$ with $0.1 \%$ TFA) for 2 min followed by a linear gradient of buffer $\mathrm{B}$ (acetonitrile $/ \mathrm{H}_{2} \mathrm{O}$ 95:5 with $0.1 \%$ TFA) into buffer $\mathrm{A}(0-100 \%$ or $0-50 \%)$ over $30 \mathrm{~min}$ at a flow rate of $1.0 \mathrm{~mL} \cdot \mathrm{min}^{-1}$. Purification of the peptidic compounds was performed on an Agilent Technologies 1260 infinity preparative system using both UV and ELSD detectors with a Phenomenex Gemini C18 column $(110 \AA \AA, 10 \mu \mathrm{m}, 250 \times 20 \mathrm{~mm})$ or Dr. Maisch Reprosil Gold $200 \mathrm{C} 18(10 \mu \mathrm{m}, 250 \times 20 \mathrm{~mm})$. Autocollection of fractions was used based on the UV measurements at $214 \mathrm{~nm}$, using a standard protocol: $80 \%$ buffer A for 5 min followed by a linear gradient of buffer B into buffer A $(0-50 \%$ or $20-60 \%)$ over $60 \mathrm{~min}$ at a flow rate of $12.5 \mathrm{~mL} \cdot \mathrm{min}^{-1}$ using the same buffers as described for the analytical HPLC. Liquid chromatography mass spectrometry (LCMS) was carried out on a Thermo Scientific LCQ Fleet quadrupole mass spectrometer with a Dionex Ultimate 3000 LC using a Dr. Maisch Reprosil Gold 120 C18 column (110 A, $3 \mu \mathrm{m}, 150 \times 4.0 \mathrm{~mm}$ ) and the same linear gradients of buffer $B$ into buffer $\mathrm{A}$, flow rate and buffers as described for the analytical HPLC.

General Method for Automated Peptide Synthesis. The peptides were synthesized on a PTI Tribute-UV peptide synthesizer. Tentagel S RAM resin $(1.0 \mathrm{~g}, 0.25 \mathrm{mmol}, 1.0$ equiv or $400 \mathrm{mg}, 0.1 \mathrm{mmol}, 1.0$ equiv) was allowed to swell in DMF $(3 \times 10 \mathrm{~min})$. Deprotection of the Fmoc group was achieved by treatment of the resin with $20 \%$ piperidine in DMF using the RV_top_UV_Xtend protocol from the Tribute-UV peptide synthesizer followed by a DMF washing step $(5 \times 30 \mathrm{~s})$. The Fmoc-protected amino acids were coupled using HCTU (with 
the $0.1 \mathrm{mmol}$ scale 5 equiv was used and with the $0.25 \mathrm{mmol}$ scale 4 equiv was used) and DiPEA (with the $0.1 \mathrm{mmol}$ scale 10 equiv was used and with the $0.25 \mathrm{mmol}$ scale 8 equiv was used) in DMF, as a coupling system, with 2 min preactivation. The coupling time was $10 \mathrm{~min}$ when the peptide was synthesized on a $0.1 \mathrm{mmol}$ scale and $20 \mathrm{~min}$ when the $0.25 \mathrm{mmol}$ scale was conducted. After every coupling the resin was washed with DMF $(6 \times 30 \mathrm{~s})$. After coupling of the last amino acid, the Fmoc group was cleaved using the normal deprotection conditions (described above) and the resulting free N-terminus was acetylated by treating the resin bounded peptide with acetic anhydride $(250 \mu \mathrm{L})$ and DiPEA (10 equiv for the $0.1 \mathrm{mmol}$ scale and 8 equiv for the $0.25 \mathrm{mmol}$ scale) in DMF using the standard coupling times (described above). In the last step the resin was washed with DMF $(5 \times 30 \mathrm{~s})$, DCM $(5 \times 30 \mathrm{~s})$, and dried over a nitrogen flow for $10 \mathrm{~min}$, followed by the cleavage of the resin-bounded peptide. Cleavage and deprotection was achieved by treatment of the resin with TFA $/ \mathrm{H}_{2} \mathrm{O} / \mathrm{TIS} / \mathrm{EDT}$ (15 mL for the $0.25 \mathrm{mmol}$ scale and $5 \mathrm{~mL}$ for the $0.1 \mathrm{mmol}$ scale, 90:5:2.5:2.5, $v / v / v / v)$ for $3 \mathrm{~h}$ at rt. The peptide was precipitated in MTBE/hexane $(1: 1,90 \mathrm{~mL}$ for the $0.25 \mathrm{mmol}$ scale and $45 \mathrm{~mL}$ for the $0.1 \mathrm{mmol}$ scale), centrifuged, the supernatant decanted and the pellet washed 5 times with MTBE/hexane $(1: 1,45 \mathrm{~mL})$. The resulting pellet was redissolved in $t-\mathrm{BuOH} / \mathrm{H}_{2} \mathrm{O}(1: 1, v / v)$ and lyophilized.

General Method for Peptide Alkylation. Crude precursor peptide $(25 \mu \mathrm{mol} ; 1.0$ equiv) was dissolved in DMF (18 mL). Subsequently, a solution of cyclization (7) or linear (8) linker ( $37.5 \mu \mathrm{mol} ; 1.5$ equiv) in DMF $(1 \mathrm{~mL})$ was added. Subsequently, an aqueous $\mathrm{NH}_{4} \mathrm{HCO}_{3}$ buffer solution ( $\mathrm{pH} 7.9,20 \mathrm{mM} ; 6 \mathrm{~mL}$ ) was added dropwise to the reaction mixture, which gave a general peptide concentration of $\leq 1 \mathrm{mM}$ in DMF/buffer solution $(3: 1, v / v)$. The reaction mixture was stirred for $2 \mathrm{~h}$ at room temperature, followed by concentration in vacuo. The residue was redissolved in TFA/ $\mathrm{H}_{2} \mathrm{O} / \mathrm{TIS} / \mathrm{EDT}$ (15 mL, 90:5:2.5:2.5, $v / v / v / v)$ and the resulting reaction mixture was stirred for $3 \mathrm{~h}$ at room temperature. Then, the crude product was precipitated in $2 \times 50 \mathrm{~mL} \mathrm{MTBE} /$ hexane $(1: 1, v / v)$. The crude precipitate was obtained by centrifugation (4500 rpm, $5 \mathrm{~min}$ ). The collected precipitate was washed an additional four times using $2 \times 50 \mathrm{~mL} \mathrm{MTBE} /$ hexane $(1: 1, v /$ $v$ ) and centrifugation $(4500 \mathrm{rpm}, 5 \mathrm{~min})$. After this the crude product was dissolved in $t \mathrm{BuOH} / \mathrm{H}_{2} \mathrm{O}(1: 1, v / v)$ and lyophilized.

Monoclonal Antibodies. The human-mouse chimeric antibody cHC84.1 was generated by grafting the nucleotide sequences encoding the variable heavy and variable light chain of human mAb HC84.1 (10) on the mouse IgG1 backbone. The resulting chimeric antibody was expressed in HEK-293T cells and purified using protein-G affinity chromatography. The mouse mAb V3.2 was generated by immunizing mice with recombinant virus-like particles of $\mathrm{HCV}$. Like HC84.1, the epitope of V3.2 recognizes amino acid residues within the epitope II region of $\mathrm{HCV}$ E2 glycoprotein. A detailed characterization of this antibody will be reported elsewhere.

General Method for ELISA. Pierce maleimide activated 96well plates were purchased from Thermo Scientific. The wells were washed three times with $200 \mu \mathrm{L}$ wash buffer $(0.1 \mathrm{M}$ $\mathrm{Na}_{3} \mathrm{PO}_{4}, 0.15 \mathrm{M} \mathrm{NaCl}, 0.05 \%$ Tween-20 detergent; $\mathrm{pH}$ 7.2). Then, the desired epitope mimic $(100-500 \mu \mathrm{g})$ was suspended in $1 \mathrm{~mL}$ binding buffer $\left(0.1 \mathrm{M} \mathrm{Na}_{3} \mathrm{PO}_{4}, 0.15 \mathrm{M} \mathrm{NaCl}, 10 \mathrm{mM}\right.$ EDTA; $\mathrm{pH}$ 7.2) and further diluted (10-50 fold) to a concentration of $10 \mu \mathrm{g} / \mathrm{mL}$. To each well, $200 \mu \mathrm{L}$ of the epitope mimic solution was added and incubated overnight at 4 ${ }^{\circ} \mathrm{C}$. After this, the wells were washed three times with $200 \mu \mathrm{L}$ wash buffer. For capping unreacted maleimide groups, immediately before use, a solution of $10 \mu \mathrm{g} / \mathrm{mL} \mathrm{N}$-acetylated cysteine was prepared and $200 \mu \mathrm{L}$ was added to each of the wells, followed by incubation for $1-2 \mathrm{~h}$ at room temperature. Then, the wells were washed three times with $200 \mu \mathrm{L}$ wash buffer. A 3-fold dilution series of primary $\mathrm{mAb}$ was prepared in wash buffer and $100 \mu \mathrm{L}$ was transferred to each well, followed by incubation for $1-2 \mathrm{~h}$ at room temperature. After this, the wells were washed three times with PBST, before supplying 100 $\mu \mathrm{L} \quad$ 1:2000 secondary HRP-conjugated $\alpha$-mouse A4416 (Sigma) antibodies in wash buffer to each well. Incubation continued for $1-2 \mathrm{~h}$ at room temperature, followed by washing the wells three times with PBST. The plates were developed

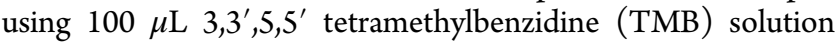
per well, obtained from Life Technologies, and incubating for $25 \mathrm{~min}$ at room temperature, after which, further development was stopped using $200 \mu \mathrm{L} 0.5 \mathrm{M} \mathrm{H}_{2} \mathrm{SO}_{4}$ per well. Absorbance at $450 \mathrm{~nm}$ was measured on a Varioskan (Thermoscientific) or PHERAstar FS (BMG Labtech) instrument.

Tetraethylene Glycol p-Toluenesulfonate (2). All steps were carried out under $\mathrm{N}_{2}$ atmosphere. Commercially available TEG 1 ( $8.6 \mathrm{~mL}, 50.0 \mathrm{mmol}, 2.0$ equiv) was dissolved in dry $\mathrm{CH}_{2} \mathrm{Cl}_{2}(100 \mathrm{~mL})$. The resulting solution was cooled to $0{ }^{\circ} \mathrm{C}$ using an ice bath, followed by addition of TEA $(7.0 \mathrm{~mL}, 50.0$ mmol, 2.0 equiv). After $1 \mathrm{~h} p$-toluenesulfonyl chloride ( $4.8 \mathrm{~g}, 25$ mmol, 1.0 equiv) was added, the ice bath was removed, and the resulting reaction mixture was stirred for $16 \mathrm{~h}$ at room temperature. Next, the reaction mixture was washed with $1 \mathrm{M}$ $\mathrm{HCl}(\mathrm{aq})(2 \times 100 \mathrm{~mL})$ and $\mathrm{H}_{2} \mathrm{O}(100 \mathrm{~mL})$. The obtained aqueous layers were combined and back-extracted with $\mathrm{CH}_{2} \mathrm{Cl}_{2}$ $(100 \mathrm{~mL})$. All $\mathrm{CH}_{2} \mathrm{Cl}_{2}$ layers were combined and washed with brine $(200 \mathrm{~mL})$ and dried over $\mathrm{Na}_{2} \mathrm{SO}_{4}$, followed by filtration. The filtrate was concentrated in vacuo, affording the crude product as a yellowish syrup. Purification by automated flash column chromatography (100\% EtOAc) afforded tetraethylene glycol $p$-toluenesulfonate (2) (5.4 g, $15.4 \mathrm{mmol}, 61 \%)$ as a clear yellowish syrup. $\mathrm{R}_{\mathrm{f}}=0.45\left(\right.$ EtOAc); $t_{\mathrm{R}}=25.0 \mathrm{~min} ;{ }^{1} \mathrm{H} \mathrm{NMR}$ $\left(400 \mathrm{MHz}, \mathrm{CDCl}_{3}\right): \delta=7.79\left(\mathrm{~d},{ }^{3} J_{\mathrm{HH}}=8.2 \mathrm{~Hz}, 2 \mathrm{H}\right.$, aryl $\left.-H\right)$, $7.34\left(\mathrm{~m},{ }^{3} \mathrm{~J}_{\mathrm{HH}}=8.2 \mathrm{~Hz}, 2 \mathrm{H}\right.$, aryl $\left.-H\right), 4.16\left(\mathrm{~m},{ }^{3} \mathrm{~J}_{\mathrm{HH}}=4.8 \mathrm{~Hz}\right.$, $2 \mathrm{H}$, TosOCH $\left.\mathrm{CH}_{2}\right), 3.70\left(\mathrm{~m}, 4 \mathrm{H}, 2 \times \mathrm{CH}_{2}\right), 3.64(\mathrm{~m}, 2 \mathrm{H}, 4 \times$ $\left.\mathrm{CH}_{2}\right), 3.60\left(\mathrm{~m}, 6 \mathrm{H}, 3 \times \mathrm{CH}_{2}\right), 2.44\left(\mathrm{~s}, 3 \mathrm{H}, \mathrm{CH}_{3}\right) 2.35$ (broad s, $1 \mathrm{H}, \mathrm{OH}) \mathrm{ppm} ;{ }^{13} \mathrm{C} \mathrm{NMR}\left(101 \mathrm{MHz}, \mathrm{CDCl}_{3}\right): 144.8$ (aryl-C), 133.1 (aryl- $\mathrm{C}), 129.8$ (m-aryl- $\mathrm{CH}), 128.0$ (o-aryl- $\mathrm{CH}), 72.5$ $\left(\mathrm{CH}_{2}\right), 70.8\left(\mathrm{CH}_{2}\right), 70.7\left(\mathrm{CH}_{2}\right), 70.5\left(\mathrm{CH}_{2}\right), 70.4\left(\mathrm{CH}_{2}\right), 69.2$ $\left(\mathrm{TosOCH}_{2}\right), 68.7\left(\mathrm{CH}_{2}\right), 61.8\left(\mathrm{CH}_{2}\right), 21.64\left(\mathrm{CH}_{3}\right)$; HRMS: calculated $\mathrm{m} / z$ for $\mathrm{C}_{15} \mathrm{H}_{24} \mathrm{NaO}_{7} \mathrm{~S}$ : $371.1135[\mathrm{M}+\mathrm{Na}]^{+1}$; found 371.1128.

Triphenylmethanethiol (3). All steps were carried out under $\mathrm{N}_{2}$ atmosphere. Commercially available trityl chloride (13.9 g, $50.0 \mathrm{mmol}, 1.0$ equiv) was dissolved in acetone (200 $\mathrm{mL}$ ). The resulting solution was added to a vigorously stirring solution of $\mathrm{NaSH}_{2} \mathrm{H}_{2} \mathrm{O}$ (11.3 g, $201.2 \mathrm{mmol}, 4.0$ equiv) in acetone $/ \mathrm{H}_{2} \mathrm{O} \quad 1: 1, \mathrm{v} / \mathrm{v}(400 \mathrm{~mL})$. The resulting reaction mixture was stirred at room temperature for $15 \mathrm{~min}$. Then, additional $\mathrm{H}_{2} \mathrm{O}(200 \mathrm{~mL})$ was added to the reaction mixture and stirring was continued for $1 \mathrm{~h}$. The crude product precipitated as a yellow solid, which was filtered and was washed thoroughly with $\mathrm{H}_{2} \mathrm{O}$. The resulting yellow solid was dried in vacuo, affording $11.1 \mathrm{~g}(40.0 \mathrm{mmol}, 80 \%)$ crude triphenylmethanethiol (3), which was used without additional purification. $\mathrm{R}_{\mathrm{f}}=0.85$ (EtOAc/Petroleum Ether $40-60{ }^{\circ} \mathrm{C} 1: 9$, 
$v / v) ; t_{\mathrm{R}}=45.6 \mathrm{~min} ;{ }^{1} \mathrm{H}$ NMR $\left(400 \mathrm{MHz}, \mathrm{CDCl}_{3}\right): \delta=7.26(\mathrm{~m}$, $15 \mathrm{H}$, aryl-H), 3.08 (s, 1H, SH) ppm; ${ }^{13} \mathrm{C}$ NMR (101 MHz, $\left.\mathrm{CDCl}_{3}\right): \delta=147.2(\operatorname{aryl}-\mathrm{C}), 129.3(\operatorname{aryl}-\mathrm{CH}), 127.8$ (aryl-CH), 126.9 (aryl-CH), 62.9 (CS) ppm. HRMS: calculated $\mathrm{m} / z$ for $\mathrm{C}_{19} \mathrm{H}_{15} \mathrm{~S}: 275.0900[\mathrm{M}-\mathrm{H}]^{-}$; found 275.0892.

Tetraethylene Glycol Monotrityl Thioether (4). All steps were performed under $\mathrm{N}_{2}$ atmosphere. Crude triphenylmethylthiol 3 (11.1 g, $40.0 \mathrm{mmol}, 2.6$ equiv) was dissolved in dry THF $(100 \mathrm{~mL})$. The resulting solution was cooled to 0 ${ }^{\circ} \mathrm{C}$ using an ice bath, followed by addition of $1.6 \mathrm{~g} \mathrm{NaH}(60 \%$ in mineral oil; $40.0 \mathrm{mmol}, 2.6$ equiv). The resulting suspension was stirred for $1 \mathrm{~h}$ at $0{ }^{\circ} \mathrm{C}$. A separate solution of tetraethylene glycol p-toluenesulfonate 2 ( $5.4 \mathrm{~g}, 15.4 \mathrm{mmol}, 1.0$ equiv) was prepared in dry THF $(10 \mathrm{~mL})$, which was added to the reaction mixture at $0{ }^{\circ} \mathrm{C}$. After this, the ice bath was removed and the reaction mixture was stirred for another $15-30 \mathrm{~min}$ at room temperature. Upon completion of the reaction, as determined by TLC (EtOAc), the reaction mixture was quenched by addition of a sat. $\mathrm{NH}_{4} \mathrm{Cl}(\mathrm{aq})(100 \mathrm{~mL})$ solution while vigorously stirring for an additional $15 \mathrm{~min}$. Then, THF was removed in vacuo and EtOAc $(100 \mathrm{~mL})$ was added. The aqueous and organic layers were separated. The EtOAc layer was washed with $\mathrm{H}_{2} \mathrm{O}(2 \times 100 \mathrm{~mL})$. The combined aqueous layers were back-extracted with EtOAc $(100 \mathrm{~mL})$. The obtained organic layers were combined and washed with brine $(200 \mathrm{~mL})$, dried over $\mathrm{Na}_{2} \mathrm{SO}_{4}$, and filtered. The filtrate was concentrated in vacuo, which afforded the crude product as a yellow oil. Purification was immediately performed by automated flash column chromatography (100\% EtOAc) afforded tetraethylene glycol monotrityl thioether (4) (6.9 g, $15.2 \mathrm{mmol}$, quant.) as a yellow oil. $\mathrm{R}_{\mathrm{f}}=0.59\left(\right.$ EtOAc); $t_{\mathrm{R}}=39.1 \mathrm{~min} ;{ }^{1} \mathrm{H}$ NMR (400 $\left.\mathrm{MHz} \mathrm{CDCl}_{3}\right): \delta=7.42(\mathrm{~m}, 6 \mathrm{H}$, trityl $o-H), 7.28(\mathrm{~m}, 6 \mathrm{H}$, trityl $m-H), 7.21(\mathrm{~m}, 3 \mathrm{H}, p-H), 3.70\left(\mathrm{~m}, 2 \mathrm{H}, \mathrm{CH}_{2} \mathrm{OH}\right), 3.64(\mathrm{~m}, 4 \mathrm{H}$, $\left.\mathrm{CH}_{2}\right), 3.58\left(\mathrm{~m}, 4 \mathrm{H}, \mathrm{CH}_{2}\right), 3.45\left(\mathrm{~m}, 2 \mathrm{H}, \mathrm{CH}_{2}\right), 3.30\left(\mathrm{t},{ }^{3} \mathrm{~J}_{\mathrm{HH}}=\right.$ $\left.6.9 \mathrm{~Hz}, 2 \mathrm{H}, \mathrm{SCH}_{2} \mathrm{CH}_{2} \mathrm{O}\right), 2.44\left(\mathrm{t},{ }^{3} \mathrm{~J}_{\mathrm{HH}}=6.9 \mathrm{~Hz}, 2 \mathrm{H}, \mathrm{SCH}_{2}\right)$, 2.34 (broad s, $1 \mathrm{H}, \mathrm{OH}) \mathrm{ppm} ;{ }^{13} \mathrm{C}$ NMR $\left(101 \mathrm{MHz}, \mathrm{CDCl}_{3}\right): \delta$ = 144.8 (Ar-C), 129.6 (o-Ar- $\mathrm{CH}), 127.9(m-\mathrm{Ar}-\mathrm{CH}), 126.6$ ( $p$ $\mathrm{Ar}-\mathrm{CH}), 72.5\left(\mathrm{CH}_{2}\right), 70.7\left(\mathrm{CH}_{2}\right), 70.5\left(\mathrm{CH}_{2}\right), 70.4\left(\mathrm{CH}_{2}\right), 70.2$ $\left(\mathrm{CH}_{2}\right), 69.7\left(\mathrm{SCH}_{2} \mathrm{CH}_{2} \mathrm{O}\right), 66.6(\mathrm{SC}), 61.8\left(\mathrm{CH}_{2}\right), 31.7$ $\left(\mathrm{SCH}_{2}\right)$; HRMS: calculated $m / z$ for $\mathrm{C}_{27} \mathrm{H}_{32} \mathrm{NaO}_{4} \mathrm{~S}: 475.1914$ $[\mathrm{M}+\mathrm{Na}]^{+1}$; found 475.1900 .

Benzylic Bromide Linkers. All steps were carried out under $\mathrm{N}_{2}$ atmosphere. Tetraethylene glycol monotrityl thioether 4 ( $3.4 \mathrm{~g}, 7.6 \mathrm{mmol})$ was dissolved in dry THF (50 $\mathrm{mL})$. The resulting solution was cooled to $0{ }^{\circ} \mathrm{C}$ using an ice bath, followed by the addition of $0.5 \mathrm{~g} \mathrm{NaH}$ ( $60 \%$ in mineral oil; 11.4 mmol, 1.5 equiv). After this, the reaction mixture was stirred for $1 \mathrm{~h}$ at $0{ }^{\circ} \mathrm{C}$. Then, tetraethylene glycol monotrityl thioether 4 was added in portions to a solution of $1,3,5$ tris(bromomethyl)benzene 5 or $\alpha, \alpha^{\prime}$-dibromide- $m$-xylene $\mathbf{6}$ and stirring continued for $16 \mathrm{~h}$. Upon completion of the reaction, as determined by TLC (30\% EtOAc in petroleum ether 40-60 $\left.{ }^{\circ} \mathrm{C}\right)$, THF was removed in vacuo. Then, the residue was dissolved in EtOAc, followed by filtration over Celite to remove salts. The filtrate was concentrated in vacuo, which afforded the crude product. Purification by automated flash column chromatography using a linear gradient (10-30\% EtOAc in petroleum ether $40-60{ }^{\circ} \mathrm{C}$ over 20 column volumes) afforded pure product.

Cyclization Linker (7). 1,3,5-Tris(bromomethyl)benzene 5 ( $1.5 \mathrm{~g}, 4.2 \mathrm{mmol}$, 1.1 equiv) was dissolved in dry THF $(75 \mathrm{~mL})$, followed by the portionwise addition $(5 \times 5 \mathrm{~mL})$ of the abovedescribed reaction mixture containing tetraethylene glycol monotrityl thioether 4 (1.7 g, $3.8 \mathrm{mmol}, 1.0$ equiv) with 15 min intervals. Purification as described above afforded pure cyclization linker (7) $(0.9 \mathrm{~g}, 1.3 \mathrm{mmol}, 33 \%)$ as a yellow oil. $\left(\mathrm{R}_{\mathrm{f}}\right.$ $=0.31$ (petroleum ether $40-60{ }^{\circ} \mathrm{C} /$ EtOAc $\left.7: 3, v / v\right) ; t_{\mathrm{R}}=49.1$ min; ${ }^{1} \mathrm{H}$ NMR $\left(400 \mathrm{MHz}, \mathrm{CDCl}_{3}\right): \delta=7.41(\mathrm{~m}, 6 \mathrm{H}, o$-trityl$\mathrm{CH}), 7.32(\mathrm{~m}, 1 \mathrm{H}, p$-aryl-CH), $7.29(\mathrm{~m}, 2 \mathrm{H}, o$-aryl-CH), 7.27 (m, 6H, m-trityl-CH), $7.21(\mathrm{~m}, 3 \mathrm{H}, p$-trityl- $\mathrm{CH}), 4.53(\mathrm{~s}, 2 \mathrm{H}$, $\mathrm{OCH}_{2}$-aryl), $4.45\left(\mathrm{~s}, 4 \mathrm{H}, 2 \times \mathrm{CH}_{2} \mathrm{Br}\right), 3.66\left(\mathrm{~m}, 8 \mathrm{H}, 4 \times \mathrm{CH}_{2}\right)$, $3.58\left(\mathrm{~m}, 2 \mathrm{H}, \mathrm{CH}_{2}\right), 3.45\left(\mathrm{~m}, 2 \mathrm{H}, \mathrm{CH}_{2}\right), 3.30\left(\mathrm{t},{ }^{3} \mathrm{~J}_{\mathrm{HH}}=6.9 \mathrm{~Hz}\right.$, $\left.2 \mathrm{H}, \mathrm{SCH}_{2} \mathrm{CH}_{2}\right), 2.43\left(\mathrm{t},{ }^{3} \mathrm{~J}_{\mathrm{HH}}=6.9 \mathrm{~Hz}, 2 \mathrm{H}, \mathrm{SCH}_{2}\right) \mathrm{ppm} ;{ }^{13} \mathrm{C}$ NMR (101 MHz, $\mathrm{CDCl}_{3}$ ): $\delta=144.8$ (trityl-C), 139.9 (aryl$\left.\mathrm{C}(\mathrm{CH})_{2}\right), 138.5\left(\operatorname{aryl}-\mathrm{C}\left(\mathrm{CH}_{2} \mathrm{Br}\right)_{2}\right), 129.6$ (o-trityl- $\left.\mathrm{CH}\right), 128.8$ (aryl- $\left.\mathrm{CH}\left(\mathrm{CCH}_{2} \mathrm{Br}\right)_{2}\right), 128.1$ (o-aryl- $\left.\mathrm{CH}\right), 127.9$ (m-trityl- $\left.\mathrm{CH}\right)$, 126.6 ( $p$-trityl- $\mathrm{CH}), 72.5\left(\mathrm{OCH}_{2}\right.$-aryl $), 70.7\left(2 \times \mathrm{CH}_{2}\right), 70.6$ $\left(\mathrm{CH}_{2}\right), 70.5\left(\mathrm{CH}_{2}\right), 70.2\left(\mathrm{CH}_{2}\right), 69.9\left(\mathrm{CH}_{2}\right), 69.6\left(\mathrm{SCH}_{2} \mathrm{CH}_{2}\right)$, 66.6 (CS), $32.8\left(\mathrm{CH}_{2} \mathrm{Br}\right), 31.7\left(\mathrm{SCH}_{2}\right)$ ppm; HRMS: calculated $m / z$ for $\mathrm{C}_{36} \mathrm{H}_{40} \mathrm{NaO}_{4} \mathrm{~S}^{79} \mathrm{Br}_{2}: 749.0906[M+\mathrm{Na}]^{+1}$; found 749.0886 .

Linear Linker (8). $\alpha, \alpha^{\prime}$-Dibromide-m-xylene 6 (1.1 g, 4.2 mmol, 1.1 equiv) was dissolved in dry THF $(75 \mathrm{~mL})$, followed by the portionwise addition $(5 \times 5 \mathrm{~mL})$ of the above-described reaction mixture containing tetraethylene glycol monotrityl thioether 4 ( $1.7 \mathrm{~g}$, $3.8 \mathrm{mmol}$, 1.0 equiv) with $15 \mathrm{~min}$ intervals. Purification as described above afforded pure cyclization linker (8) $(1.0 \mathrm{~g}, 1.6 \mathrm{mmol}, 43 \%)$ as a yellow oil $\mathrm{R}_{\mathrm{f}}=0.36$ (petroleum ether $40-60{ }^{\circ} \mathrm{C} /$ EtOAc $\left.7: 3, v / v\right) ; t_{\mathrm{R}}=48.3 \mathrm{~min} ;{ }^{1} \mathrm{H} \mathrm{NMR}$ $\left(400 \mathrm{MHz}, \mathrm{CDCl}_{3}\right): \delta=7.41(\mathrm{~m}, 6 \mathrm{H}, o$-trityl-CH$), 7.37(\mathrm{~m}$, $1 \mathrm{H}, p$-aryl-CH), $7.30(\mathrm{~m}, 3 \mathrm{H}, o$-aryl-CH), $7.27(\mathrm{~m}, 6 \mathrm{H}, m-$ trityl-CH), $7.21\left(\mathrm{~m}, 3 \mathrm{H}, \mathrm{p}\right.$-trityl-CH), $4.54\left(\mathrm{~s}, 2 \mathrm{H}, \mathrm{OCH}_{2^{-}}\right.$ aryl), $4.48\left(\mathrm{~s}, 4 \mathrm{H}, 2 \times \mathrm{CH}_{2} \mathrm{Br}\right), 3.64\left(\mathrm{~m}, 8 \mathrm{H}, 4 \times \mathrm{CH}_{2}\right), 3.57$ $\left(\mathrm{m}, 2 \mathrm{H}, \mathrm{CH}_{2}\right), 3.45\left(\mathrm{~m}, 2 \mathrm{H}, \mathrm{CH}_{2}\right), 3.30\left(\mathrm{t},{ }^{3} \mathrm{~J}_{\mathrm{HH}}=6.9 \mathrm{~Hz}, 2 \mathrm{H}\right.$, $\left.\mathrm{SCH}_{2} \mathrm{CH}_{2}\right), 2.42=\left(\mathrm{t},{ }^{3} J_{\mathrm{HH}}=6.9 \mathrm{~Hz}, 2 \mathrm{H}, \mathrm{SCH}_{2}\right) \mathrm{ppm} ;{ }^{13} \mathrm{C}$ $\operatorname{NMR}\left(101 \mathrm{MHz}, \mathrm{CDCl}_{3}\right): \delta=144.8$ (trityl-C), 139.1 (aryl$\left.\mathrm{C}(\mathrm{CH})_{2}\right), 137.9$ (aryl-CCH $\left.\mathrm{C}_{2} \mathrm{Br}\right), 129.6$ (o-trityl- $\left.\mathrm{CH}\right), 128.8$ (aryl-CCH $\left.\left(\mathrm{CCH}_{2} \mathrm{Br}\right)\right), 128.2$ (aryl- $\left.\mathrm{CH}\right), 127.9$ (m-trityl- $\left.\mathrm{CH}\right)$, 127.7 (aryl- $\mathrm{CH}), 126.6$ ( $p$-trityl- $\mathrm{CH}), 72.8\left(\mathrm{OCH}_{2}\right.$-aryl), 70.7 $\left(3 \times \mathrm{CH}_{2}\right), \quad 70.5\left(\mathrm{CH}_{2}\right), 70.2\left(\mathrm{CH}_{2}\right), 69.7\left(\mathrm{CH}_{2}\right), 69.6$ $\left(\mathrm{SCH}_{2} \mathrm{CH}_{2}\right), 66.6(\mathrm{CS}), 33.4\left(\mathrm{CH}_{2} \mathrm{Br}\right), 31.7\left(\mathrm{SCH}_{2}\right)$ ppm; HRMS: calculated $m / z$ for $\mathrm{C}_{35} \mathrm{H}_{39} \mathrm{NaO}_{4} \mathrm{~S}^{79} \mathrm{Br}$ : 657.1645 $[M$ $+\mathrm{Na}]^{+1}$; found 657.1629 .

Cyclic Precursor Peptide 9 (cp). The peptide was synthesized as described above by solid phase synthesis on a $0.25 \mathrm{mmol}$ scale, which afforded crude peptide $(397.9 \mathrm{mg}$ ). This crude peptide was used in the cyclization by alkylation step. $t_{\mathrm{R}}=19.2 \mathrm{~min}$; LRMS: $\mathrm{m} / z$ calculated for $\mathrm{C}_{89} \mathrm{H}_{117} \mathrm{~N}_{21} \mathrm{O}_{19} \mathrm{~S}_{2}$ : $924.921 / 2[\mathrm{M}+2 \mathrm{H}]^{2+}$; found: $925.33\left({ }^{13} \mathrm{C}\right.$ $[+1])$.

Linear Precursor Peptide 10 (Ip). The peptide was synthesized as described above by solid phase synthesis on a $0.25 \mathrm{mmol}$ scale, which afforded crude peptide $(433.5 \mathrm{mg}$ ). This crude peptide was used in the alkylation step. $t_{\mathrm{R}}=18.9$ min; LRMS: $m / z$ calculated for $\mathrm{C}_{86} \mathrm{H}_{112} \mathrm{~N}_{20} \mathrm{O}_{18} \mathrm{~S}: 873.421 /$ $2[\mathrm{M}+2 \mathrm{H}]^{2+}$; found: $873.92\left({ }^{13} \mathrm{C}[+1]\right)$.

Cyclic Precursor Peptide 11 (cp). The peptide was synthesized as described above by solid phase synthesis on a $0.25 \mathrm{mmol}$ scale, which afforded crude peptide $(322.3 \mathrm{mg}$ ). This crude peptide was used in the cyclization by alkylation step. $t_{\mathrm{R}}=21.7 \mathrm{~min} ; \mathrm{m} / z$ calculated for $\mathrm{C}_{91} \mathrm{H}_{127} \mathrm{~N}_{21} \mathrm{O}_{26} \mathrm{~S}_{2}$ : $997.941 / 2[\mathrm{M}+2 \mathrm{H}]^{2+}$; found: $998.08\left({ }^{13} \mathrm{C}[+1]\right)$.

Linear Precursor Peptide 12 (Ip). The peptide was synthesized as described above by solid phase synthesis on a $0.25 \mathrm{mmol}$ scale, which afforded crude peptide $(390.5 \mathrm{mg}$ ). This crude peptide was used in the alkylation step. $t_{\mathrm{R}}=21.5$ 
min; $m / z$ calculated for $\mathrm{C}_{88} \mathrm{H}_{122} \mathrm{~N}_{20} \mathrm{O}_{25} \mathrm{~S}$ : $946.44 \quad 1 / 2[\mathrm{M}$ $+2 \mathrm{H}]^{2+}$; found: $946.75\left({ }^{13} \mathrm{C}[+1]\right)$.

Cyclic Precursor Peptide 13 (cp). The peptide was synthesized as described above by solid phase synthesis on a $0.25 \mathrm{mmol}$ scale, which afforded crude peptide $(382.7 \mathrm{mg})$. This crude peptide was used in the cyclization by alkylation step. $t_{\mathrm{R}}=19.7 \mathrm{~min} ; \mathrm{m} / z$ calculated for $\mathrm{C}_{90} \mathrm{H}_{119} \mathrm{~N}_{21} \mathrm{O}_{19} \mathrm{~S}_{2}$ : $931.931 / 2[\mathrm{M}+2 \mathrm{H}]^{2+}$; found: 932.33 .

Cyclic Precursor Peptide 14 (cp). The peptide was synthesized as described above by solid phase synthesis on a $0.25 \mathrm{mmol}$ scale, which afforded crude peptide $(332.3 \mathrm{mg}$ ). This crude peptide was used in the cyclization by alkylation step. $t_{\mathrm{R}}=19.1 \mathrm{~min} ; \mathrm{m} / z$ calculated for $\mathrm{C}_{90} \mathrm{H}_{119} \mathrm{~N}_{21} \mathrm{O}_{19} \mathrm{~S}_{2}$ : $931.931 / 2[\mathrm{M}+2 \mathrm{H}]^{2+}$; found: $932.50\left({ }^{13} \mathrm{C}[+1]\right)$.

Cyclic Epitope Mimic 15. Crude cyclic precursor 9 (cp) (46.2 mg, $25 \mu \mathrm{mol}, 1.0$ equiv) was treated with cyclization linker 7 ( $27.3 \mathrm{mg}, 38 \mu \mathrm{mol}, 1.5$ equiv) according to the general method for peptide alkylation as described above. The obtained crude product $(53.9 \mathrm{mg}$ ) was dissolved in HPLC buffers A and $\mathrm{B}(1: 1, v / v)$ as three batches of $10-20 \mathrm{mg}$ in $3 \mathrm{~mL}$. Each batch was purified by preparative HPLC using a linear gradient of HPLC buffer B in HPLC buffer A (0-50\%; $60 \mathrm{~min})$. Fractions containing pure product were combined and lyophilized to yield pure cyclic epitope mimic $\mathbf{1 5}(9.7 \mathrm{mg}, 15.4 \%$ overall yield; 95\% average yield per step) as a fluffy white powder. $t_{\mathrm{R}}=21.6$ min; LRMS: calculated $m / z$ for $\mathrm{C}_{106} \mathrm{H}_{141} \mathrm{~N}_{21} \mathrm{O}_{23} \mathrm{~S}_{3}: 1087.001 /$ $2[M+2 \mathrm{H}]^{+2}$; found $1087.50\left({ }^{13} \mathrm{C}[+1]\right)$; HRMS: calculated $m / z$ for $\mathrm{C}_{106} \mathrm{H}_{141} \mathrm{~N}_{21} \mathrm{O}_{23} \mathrm{~S}_{3}$ : $1086.99141 / 2[M+2 \mathrm{H}]^{+2}$; found 1086.9400.

Linear Epitope Mimic 16. Crude linear precursor 10 (lp) (66.4 mg, $38 \mu \mathrm{mol}, 1.0$ equiv) was treated with linear linker 8 ( $35.9 \mathrm{mg}, 57 \mu \mathrm{mol}, 1.5$ equiv) according to the general method for peptide alkylation as described above. The obtained crude product $(67.8 \mathrm{mg})$ was dissolved in HPLC buffers A and B $(1: 1, v / v)$ as two batches of $20-40 \mathrm{mg}$ in $2-5 \mathrm{~mL}$. Each batch was purified by preparative HPLC using a linear gradient of HPLC buffer B in HPLC buffer A (0-50\%; $60 \mathrm{~min})$. Fractions containing pure product were combined and lyophilized to yield pure linear epitope mimic 16 (23.1 mg, 29.3\% overall yield; $96 \%$ average yield per step) as a fluffy white powder. $t_{\mathrm{R}}=$ $22.1 \mathrm{~min}$; LRMS: calculated $\mathrm{m} / z$ for $\mathrm{C}_{102} \mathrm{H}_{136} \mathrm{~N}_{20} \mathrm{O}_{22} \mathrm{~S}_{2}$ : $1029.491 / 2[\mathrm{M}+2 \mathrm{H}]^{+2}$; found $1030.00\left({ }^{13} \mathrm{C}[+1]\right)$; HRMS: calculated $m / z$ for $\mathrm{C}_{102} \mathrm{H}_{136} \mathrm{~N}_{20} \mathrm{O}_{22} \mathrm{~S}_{2}$ : $1029.4868 \quad 1 / 2[M$ $+2 \mathrm{H}]^{+2}$; found 1029.4826 .

Cyclic Epitope Mimic 17. Crude cyclic precursor 11 (cp) (50.5 mg, $25 \mu \mathrm{mol}, 1.0$ equiv) was treated with cyclization linker 7 ( $27.7 \mathrm{mg}, 38 \mu \mathrm{mol}, 1.5$ equiv) according to the general method for peptide alkylation as described above. The obtained crude product $(60.7 \mathrm{mg})$ was dissolved in HPLC buffers A and $\mathrm{B}(1: 1, v / v)$ as three batches of, respectively, $15-25 \mathrm{mg}$ in 3 $\mathrm{mL}$. Each batch was purified by preparative HPLC using a linear gradient of HPLC buffer B in HPLC buffer A (20-60\%; $60 \mathrm{~min}$ ). Fractions containing pure product were combined and lyophilized to yield pure cyclic epitope mimic 17 (4.3 mg, 4.7\% overall yield; $93 \%$ average yield per step) as a fluffy white powder. $t_{\mathrm{R}}=22.6 \mathrm{~min}$; LRMS: calculated $\mathrm{m} / \mathrm{z}$ for $\mathrm{C}_{108} \mathrm{H}_{151} \mathrm{~N}_{21} \mathrm{O}_{30} \mathrm{~S}_{3}$ : $1160.011 / 2[M+2 \mathrm{H}]^{+2}$; found 1160.42 $\left({ }^{13} \mathrm{C}[+1]\right)$; HRMS: calculated $m / z$ for $\mathrm{C}_{108} \mathrm{H}_{151} \mathrm{~N}_{21} \mathrm{O}_{30} \mathrm{~S}_{3}$ : $1157.99711 / 2[M-2 \mathrm{H}]^{+2}$; found 1157.9971 .

Linear Epitope Mimic 18. Crude linear precursor 12 (lp) ( $72.6 \mathrm{mg}, 38 \mu \mathrm{mol}, 1.0$ equiv) was treated with linear linker 8 ( $35.9 \mathrm{mg}, 57 \mu \mathrm{mol}, 1.5$ equiv) according to the general method for peptide alkylation as described above. The obtained crude product $(77.6 \mathrm{mg}$ ) was dissolved in HPLC buffers A and B $(1: 1, v / v)$ as two batches of $20-30 \mathrm{mg}$ in $2-3 \mathrm{~mL}$. Each batch was purified by preparative HPLC using a linear gradient of HPLC buffer B in HPLC buffer A (20-60\%; $60 \mathrm{~min})$. Fractions containing pure product were combined and lyophilized to yield pure linear epitope mimic 18 (3.5 mg, $3.4 \%$ overall yield; $91 \%$ average yield per step) as a fluffy white powder. $t_{\mathrm{R}}=23.6 \mathrm{~min}$; LRMS: calculated $\mathrm{m} / z$ for $\mathrm{C}_{104} \mathrm{H}_{146} \mathrm{~N}_{20} \mathrm{O}_{29} \mathrm{~S}_{2}$ : $1102.51 \quad 1 / 2[M+2 \mathrm{H}]^{+2}$; found 1102.75 $\left({ }^{13} \mathrm{C}[+1]\right)$. HRMS: calculated $m / z$ for $\mathrm{C}_{104} \mathrm{H}_{146} \mathrm{~N}_{20} \mathrm{O}_{29} \mathrm{~S}_{2}$ : $1102.50821 / 2[M+2 \mathrm{H}]^{+2}$; not found (no ionization).

Cyclic Epitope Mimic 19. Crude cyclic precursor 13 (cp) (46.4 mg, $25 \mu \mathrm{mol}, 1.0$ equiv) was treated with cyclization linker 7 ( $27.3 \mathrm{mg}, 38 \mu \mathrm{mol}, 1.5$ equiv) according to the general method for peptide alkylation as described above. The obtained crude product $(51.2 \mathrm{mg}$ ) was dissolved in HPLC buffers A and B $(1: 1, v / v)$ as three batches of $10-20 \mathrm{mg}$ in $2-3 \mathrm{~mL}$. Each batch was purified by preparative HPLC using a linear gradient of HPLC buffer B in HPLC buffer A (0-50\%; $60 \mathrm{~min})$. Fractions containing pure product were combined and lyophilized to yield pure cyclic epitope mimic 19 (4.9 mg, $7.4 \%$ overall yield; $93 \%$ average yield per step) as a fluffy white powder. $t_{\mathrm{R}}=22.3 \mathrm{~min}$; LRMS: calculated $\mathrm{m} / \mathrm{z}$ for $\mathrm{C}_{107} \mathrm{H}_{143} \mathrm{~N}_{21} \mathrm{O}_{23} \mathrm{~S}_{3}$ : $1094.001 / 2[M+2 \mathrm{H}]^{+2}$; found 1094.50 $\left({ }^{13} \mathrm{C}[+1]\right)$; HRMS: calculated $m / z$ for $\mathrm{C}_{107} \mathrm{H}_{143} \mathrm{~N}_{21} \mathrm{O}_{23} \mathrm{~S}_{3}$ : $1093.99931 / 2[M+2 \mathrm{H}]^{+2}$; found 1093.9941 .

Cyclic Epitope Mimic 20. Crude cyclic precursor 14 (cp) (46.4 mg, $25 \mu \mathrm{mol}, 1.0$ equiv) was treated with cyclization linker 7 ( $27.3 \mathrm{mg}, 38 \mu \mathrm{mol}, 1.5$ equiv) according to the general method for peptide alkylation as described above. The obtained crude product $(50.0 \mathrm{mg})$ was dissolved in HPLC buffers A and B $(1: 1, v / v)$ as three batches of $10-20 \mathrm{mg}$ in $2-3 \mathrm{~mL}$. Each batch was purified by preparative HPLC using a linear gradient of HPLC buffer B in HPLC buffer A (0-50\%; $60 \mathrm{~min})$. Fractions containing pure product were combined and lyophilized to yield pure cyclic epitope mimic $20(6.7 \mathrm{mg}$, $8.8 \%$ overall yield; $93 \%$ average yield per step) as a fluffy white powder. $t_{\mathrm{R}}=21.8 \mathrm{~min}$; LRMS: calculated $\mathrm{m} / z$ for $\mathrm{C}_{107} \mathrm{H}_{143} \mathrm{~N}_{21} \mathrm{O}_{23} \mathrm{~S}_{3}$ : $1094.001 / 2[M+2 \mathrm{H}]^{+2}$; found 1094.50 $\left({ }^{13} \mathrm{C}[+1]\right)$; HRMS: calculated $m / z$ for $\mathrm{C}_{107} \mathrm{H}_{143} \mathrm{~N}_{21} \mathrm{O}_{23} \mathrm{~S}_{3}$ : $1093.99921 / 2[M+2 \mathrm{H}]^{+2}$; found 1093.9936 .

\section{ASSOCIATED CONTENT}

\section{Supporting Information}

The Supporting Information is available free of charge on the ACS Publications website at DOI: 10.1021/acs.bioconjchem.7b00755.

${ }^{1} \mathrm{H}$ NMR and ${ }^{13} \mathrm{C}$ NMR, including COSY, ${ }^{13} \mathrm{C}$-DEPT, and HSQC spectra; Analytical HPLC chromatograms including a chromatogram overlay of fractions taken after purification by preparative HPLC; LRMS and/or HRMS analysis (PDF)

\section{AUTHOR INFORMATION}

\section{Corresponding Authors}

*E-mail: arvind.patel@glasgow.ac.uk.

*E-mail: robert.liskamp@glasgow.ac.uk.

ORCID

Rob M. J. Liskamp: 0000-0001-8897-8975

Author Contributions

The manuscript was written through contributions of all authors. 


\section{Notes}

The authors declare no competing financial interest.

\section{ACKNOWLEDGMENTS}

Work in A.H.P.'s laboratory is supported by the MRC Core funding (MC_UU 12014/2). We are grateful to Dr. Mohammed Hezwani, Dr. Susan Gannon, and Dr. Alex Hoose for their invaluable support and helpful discussions during this study.

\section{ABBREVIATIONS}

$\mathrm{cp}$, cyclic precursor; ELISA, enzyme-linked immunosorbent assay; HCV, Hepatitis C Virus; HPLC, high performance liquid chromatography; HRMS, high resolution mass spectrometry; lp, linear precursor; LRMS, low resolution mass spectrometry; Mab, monoclonal antibody; NAb, neutralizing antibody; PBST, phosphate-buffered saline/tween; TEG, tetraethylene glycol; TLC, thin layer chromatography.

\section{REFERENCES}

(1) Hajarizadeh, B., Grebely, J., and Dore, G. J. (2013) Epidemiology and natural history of HCV infection. Nat. Rev. Gastroenterol. Hepatol. $10,553-562$.

(2) Chung, R. T., and Baumert, T. F. (2014) Curing chronic hepatitis C-the arc of a medical triumph. N. Engl. J. Med. 370, 1576-1578.

(3) Callaway, E. (2014) Hepatitis C drugs not reaching poor. Nature 508, 295-296.

(4) Midgard, H., Bjøro, B., Maeland, A., Konopski, Z., Kileng, H., Damås, J. K., Paulsen, J., Heggelund, L., Sandvei, P. K., Ringstad, J. O., et al. (2016) Hepatitis C reinfection after sustained virological response. J. Hepatol. 64, 1020-1026.

(5) Kong, L., Jackson, K. N., Wilson, I. A., and Law, M. (2015) Capitalizing on knowledge of hepatitis $\mathrm{C}$ virus neutralizing epitopes for rational vaccine design. Curr. Opin. Virol. 11, 148-157.

(6) Tarr, A. W., Khera, T., Hueging, K., Sheldon, J., Steinmann, E., Pietschmann, T., and Brown, R. J. P. (2015) Genetic diversity underlying the envelope glycoproteins of hepatitis $\mathrm{c}$ virus: structural and functional consequences and the implications for vaccine design. Viruses 7, 3995-4046.

(7) Helle, F., Goffard, A., Morel, V., Duverlie, G., McKeating, J., Keck, Z. Y., Foung, S., Penin, F., Dubuisson, F., and Voisset, C. (2007) The neutralizing activity of anti-hepatitis $C$ virus antibodies is modulated by specific glycans on the E2 glycoprotein. J. Virol. 81, 8101-8111.

(8) Sautto, G., Tarr, A. W., Mancini, N., and Clementi, M. (2013) Structural and antigenic definition of hepatitis C virus E2 glycoprotein epitopes targeted by monoclonal antibodies. Clin. Dev. Immunol. 2013, 450963.

(9) Keck, Z. Y., Xia, J., Wang, Y., Wang, W., Krey, T., Prentoe, J., Carlsen, T., Li, A. Y., Patel, A. H., Lemon, S. M., et al. (2012) Human monoclonal antibodies to a novel cluster of conformational epitopes on HCV E2 with resistance to neutralization escape in a fenotype 2a Isolate. PLoS Pathog. 8, e1002653.

(10) Krey, T., Meola, A., Keck, Z. Y., Damier-Piolle, L., Foung, S. K. H., and Rey, F. A. (2013) Structural basis of HCV neutralization by human monoclonal antibodies resistant to viral neutralization escape. PLoS Pathog. 9, e1003364.

(11) Ball, J. K., Tarr, A. W., and McKeating, J. A. (2014) The past, present and future of neutralizing antibodies for hepatitis $\mathrm{C}$ virus. Antiviral Res. 105, 100-111.

(12) Kong, L., Giang, E., Nieusma, T., Kadam, R. U., Cogburn, K. E., Hua, Y., Dai, X., Stanfield, R. L., Burton, D. R., Ward, A. B., et al. (2013) Hepatitis C virus E2 envelope glycoprotein core structure. Science 342, 1090-1094.

(13) Kong, L., Lee, D. E., Kadam, R. U., Liu, T., Giang, E., Nieusma, T., Garces, F., Tzarum, N., Woods, V. L., Jr., Ward, A. B., et al. (2016)
Structural flexibility at a major conserved antibody target on hepatitis $\mathrm{c}$ virus E2 antigen. Proc. Natl. Acad. Sci. U. S. A. 113, 12768-12773.

(14) Werkhoven, P. R., Van de Langemheen, H., Van der Wal, S., Kruijtzer, J. A. W., and Liskamp, R. M. J. (2014) Versatile convergent synthesis of a three peptide loop containing protein mimic of whooping cough pertactin by successive $\mathrm{Cu}(\mathrm{I})$-catalyzed azide alkyne cycloaddition on an orhtogonal alkyne functionalized TAC-scaffold. J. Pept. Sci. 20, 235-239.

(15) Werkhoven, P. R., and Liskamp, R. M. J. (2013) Chemical approaches for localization, characterization and mimicry of peptide loops. Biotherapeutics: Recent Developments using Chemical and Molecular Biology (Jones, L. H., and McKnight, A. J., Eds.) RSC Drug Discovery Series No. 36, pp 263-284, Chapter 10, The Royal Society of Chemistry, Cambridge.

(16) Mulder, G. E., Quarles van Ufford, H. C., Van Ameijde, J., Brouwer, A. J., Kruijtzer, J. A. W., and Liskamp, R. M. J. (2013) Scaffold optimization in discontinuous epitope containing protein mimics of gp120 using smart libraries. Org. Biomol. Chem. 11, 26762684.

(17) Werkhoven, P. R., Elwakiel, M., Meuleman, T. J., Quarles van Ufford, H. C., Kruijtzer, J. A. W., and Liskamp, R. M. J. (2016) Molecular construction of HIV-gp120 discontinuous epitope mimics by assembly of cyclic peptides on an orthogonal alkyne functionalized TAC-scaffold. Org. Biomol. Chem. 14, 701-710.

(18) Skwarczynski, M., and Toth, I. (2016) Peptide-Based Synthetic Vaccines. Chem. Sci. 7, 842-854.

(19) Robinson, J. A. (2013) Max Bergmann lecture: Protein epitope mimetics in the age of structural vaccinology. J. Pept. Sci. 19, 127-140.

(20) Udugamasooriya, D. G., and Spaller, M. R. (2008) Conformational Constraints in Protein Ligand Design and the inconsistency of binding entropy. Biopolymers 89, 653-667.

(21) Hill, T. A., Shepherd, N. E., Diness, F., and Fairlie, D. P. (2014) Constraining cyclic peptides to mimic protein structure motifs. Angew. Chem., Int. Ed. 53, 13020-13041.

(22) Cardote, T. A. F., and Cuilli, A. (2016) Cyclic and macrocyclic peptides as chemical tools to recognize protein surfaces and probe protein-protein interactions. ChemMedChem 11, 787-794.

(23) Nevola, L., and Giralt, E. (2015) Modulating protein-protein interactions: the potential of peptides. Chem. Commun. 51, 33023315.

(24) Fujiwara, D., Kitada, H., Oguri, M., Nishihara, T., Michigami, M., Shiraishi, K., Yuba, E., Nakase, I., Im, H., Cho, S., et al. (2016) (2016) A cyclized helix-loop-helix peptide as a molecular scaffold for the design of inhibitors of intracellular protein-protein interactions by epitope and arginine grafting. Angew. Chem., Int. Ed. 55, 10612-10615.

(25) Sable, R., Durek, T., Taneja, V., Craik, D. J., Pallerla, S., Gauthier, T., and Jois, S. (2016) Constrained cyclic peptides as immunomodulatory inhibitors of the $\mathrm{CD} 2: \mathrm{CD} 58$ protein-protein interaction. ACS Chem. Biol. 11, 2366-2374.

(26) Logan, M., Law, J., Wong, J. A. J-X., Hockman, D., Landi, A., Chen, C., Crawford, K., Kundu, J., Baldwin, L., Johnson, J., et al. (2017) Native Folding of a Recombinant gpE1/gpE2 heterodimer vaccine antigen from a precursor protein fused with Fc IgG. J. Virol. 91, e01552-16.

(27) Abdelhafez, T. H., Bader El Din, N. G., Tabll, A. A., Mashaly, M. M., Dawood, R. M., Yassin, N. A., and El-Awady, M. K. (2017) Mice Antibody Response to Conserved Nonadjuvanted Multiple Antigenic Peptides Derived from E1/E2 Regions of Hepatitic C Virus. Viral Immunol. 30, 359-365.

(28) Pierce, B. G., Keck, Z.-Y., Lau, P., Fauvelle, C., Gowthaman, R., Baumert, T. F., Fuerst, T. R., Mariuzza, R. A., and Foung, S. K. H. (2016) Global mapping of antibody recognition of the hepatitis $c$ virus E2 glycoprotein: implications for vaccine design. Proc. Natl. Acad. Sci. U. S. A. 113, E6946-E6954.

(29) Nieto, A., Gayá, A., Moreno, C., Jansá, M., and Vives, J. (1986) Adsorption-desorption of antigen to polystyrene plates used in ELISA. Ann. Inst. Pasteur/Immunol. 137, 161-172.

(30) Gori, A., Sola, L., Gagni, P., Bruni, G., Liprino, M., Peri, C., Colombo, G., Cretich, M., and Chiari, M. (2016) Screening Complex 
Biological Samples with Peptide Microarrays: The Favorable Impact of Probe Orientation via Chemoselective Immobilization Strategies on Clickable Polymeric Coatings. Bioconjugate Chem. 27, 2669-2677.

(31) Trzcinska, R., Balin, K., Kubacki, J., Marzec, M. E., Pedrys, R., Szade, J., Silberring, J., Dworak, A., and Trzebicka, B. (2014) Relevance of the Poly(ethylene glycol) Linkers in Peptide Surfaces for Proteases Assays. Langmuir 30, 5015-5025.

(32) Owsianka, A. M., Timms, J. M., Tarr, A. W., Brown, R. J. P., Hickling, T. P., Szwejk, A., Bienkowska- Szewczyk, K., Thomson, B. J., Patel, A. H., and Ball, J. K. (2006) Identification of conserved residues in the $\mathrm{E} 2$ envelope glycoprotein of the hepatitis $\mathrm{C}$ virus that are critical for CD81 binding. J. Virol. 80, 8695-8704.

(33) Drummer, H. E., Boo, I., Maerz, A. L., and Poumbourios, P. (2006) A conserved Gly(436)- Trp-Leu-Ala-Gly- Leu-Phe-Tyr motif in hepatitis $\mathrm{C}$ virus glycoprotein $\mathrm{E} 2$ is a determinant of CD81 binding and viral entry. J. Virol. 80, 7844-7853.

(34) Van de Langemheen, H., Korotkovs, V., Bijl, J., Wilson, C., Kale, S. S., Heinis, C., and Liskamp, R. M. J. (2017) Polar Hinges as Functionalized Conformational Constraints in (Bi)cyclic Peptides. ChemBioChem 18, 387-395. 